\title{
Use of proliferation cell nuclear antigen immunoreactivity for distinguishing hydropic abortions from partial hydatidiform moles
}

\author{
U R Suresh, R J Hale, H Fox, C H Buckley
}

\begin{abstract}
Aims: To determine whether the expression of proliferating cell nuclear antigen (PCNA) in villous cytotrophoblast could distinguish between placental tissue from a hydropic abortion and that from a partial hydatidiform mole.

Methods: Tissue from 18 partial hydatidiform moles, 15 hydropic abortions, five normal first trimester placentas and five normal full term placentas were immunostained for expression of PCNA, using the monoclonal antibody PC10.

Results: PCNA immunoreactivity was very much higher in the cytotrophoblast of normal first trimester placentas than in normal term placentas. Villous tissue from partial hydatidiform moles showed, on average, less immunoreactivity for PCNA than did villous tissue from hydropic abortions.

Conclusions: Immunostaining for PCNA is of no value for differentiating between partial hydatidiform moles and hydropic abortions. The findings indicate that trophoblastic proliferation or hyperplasia is not a feature of partial hydatidiform moles.
\end{abstract}

\section{$(\mathcal{F}$ Clin Pathol 1993;46:48-50)}

In the routine histological examination of placental tissue from abortions it can be very difficult to distinguish between a hydropic abortion and a partial hydatidiform mole, a problem which is largely responsible for the very high level of interobserver variation in the diagnosis of partial moles. ${ }^{12}$ This is despite the fact that standard descriptions of the histological features of these two entities seem to indicate sharp differences between them, particular emphasis being laid on the presence of trophoblastic hyperplasia or proliferation as a defining feature of a molar pregnancy. ${ }^{3-11}$ The distinction between a hydropic abortion and a partial mole has practical importance because women diagnosed as having a partial mole are entered into the follow up programme for patients with gestational trophoblastic disease while those thought to have a hydropic abortion are not.

Proliferating cell nuclear antigen (PCNA) is a highly conserved 36 kilodalton acidic nuclear protein, an auxiliary protein of DNA polymerase delta, and is expressed during the late G1 and $S$ phases of the cell cycle. ${ }^{12-15}$ Nuclear PCNA immunoreactivity can be demonstrated in proliferating cells using the monoclonal antibody $\mathrm{PC} 10^{1617}$ and such immunoreactivity is thought to be a marker for cell proliferation. ${ }^{18-22}$

As villous trophoblastic proliferation or hyperplasia is regarded as a defining feature of a molar gestation, while the villous trophoblast in a hydropic abortion is usually considered to be relatively or absolutely quiescent, demonstration of PCNA expression could serve as an objective means of distinguishing between these two entities.

\section{Methods}

Material from 18 partial hydatidiform moles and 15 hydropic abortions was retrieved from the files of the Department of Reproductive Pathology, St Mary's Hospital, Manchester. All the cases had been diagnosed between 1985 and 1988, and each case had been reviewed and the diagnosis confirmed by one of the authors (HF). A diagnosis of partial hydatidiform mole was based on the presence of scattered vesicular villi, often showing central cavitation and very irregular outlines, set in a villous population of normal diameter: in all cases there was some degree of what is conventionally regarded as trophoblastic hyperplasia, though the trophoblast usually showed an atypical pattern, rather than an unusual degree of growth. Sections of placental tissue were also selected from five first trimester terminations of pregnancy carried out for social reasons and from five placentas from uncomplicated full term pregnancies which had resulted in the birth of live infants of normal weight.

Tissue from all cases had been formalin fixed and paraffin wax embedded: the length of fixation was the same in all groups. Sections were cut at $4 \mu \mathrm{m}$, dewaxed, and immunostained with the monoclonal antibody PC10 (Novocastra Laboratories: NCL-PCNA) using a conventional avidin-biotin complex method (ABC complex, Dakopatts, England) with light haematoxylin counterstaining. Tissue from normal human tonsil was used as a positive control and substitution of the primary antibody by phosphate buffered saline was used as a negative control.

All immunostained sections were examined by the same observer (US) using a $\times 40$ objective. One thousand villous cytotrophoblastic cells were assessed in each case. Only cells with strong, unequivocal nuclear staining were scored positive. The results were expressed as a percentage and were analysed statistically using the Minotab program. ${ }^{23}$ 
Percentage of villous cytotrophoblastic cells staining positively for PCNA

Normal first trimester placenta Normal term placenta Hydropic abortion Partial moles

\begin{tabular}{lllll}
\hline Mean & $8 \cdot 19$ & $0 \cdot 75$ & $7 \cdot 64$ & $6 \cdot 23$ \\
Range & $7 \cdot 6-9 \cdot 1$ & $0 \cdot 2-1 \cdot 3$ & $5 \cdot 5-9 \cdot 5$ & $2 \cdot 5-9 \cdot 4$ \\
\hline
\end{tabular}

\section{Results}

The results for each of the four diagnostic categories are shown in the table. The difference in counts between first and third trimester placentas was significant $(p=0.0022)$; there was also a significant difference between the counts for normal first trimester placentas and both hydropic abortions and partial moles $(p=0047)$. The difference in counts between hydropic abortions and partial moles was not significant.

\section{Discussion}

The findings in placentas from normal pregnancies were exactly as would have been predicted. Thus in first trimester placentas there was very active growth of the trophoblast with the cytotrophoblastic cells functioning as an active germinative zone ${ }^{24}$ : at term, villous trophoblastic growth is much diminished though not, as was previously thought, absent. Our results, in this respect, were similar to those obtained by autoradiography, ${ }^{25}$ total organ DNA analysis, ${ }^{26}$ flow cytometry ${ }^{27}$ and morphometric analysis. ${ }^{28}$ In normal trophoblast, therefore, PCNA seems to serve as an excellent index of proliferative activity.

The results obtained in aborted placentas and in trophoblast from partial hydatidiform moles were, however, the precise reverse of those which we would have predicted. Indeed, these results have forced us to reappraise the conventional view of trophoblastic proliferation in molar pregnancies. In hydropic abortions the mean count of cells staining positively for PCNA was lower than that for normal first trimester placentas, though in $50 \%$ of such cases the values noted fell within the range obtained for normal first trimester trophoblastic tissue. It has to be borne in mind that after fetal death the trophoblast is still fully viable and continues to function, albeit at a diminished level, as indicated by depressed maternal concentrations of hCG, progesterone, and oestradiol. ${ }^{29}$ The findings in the trophoblast of hydropic abortions were, therefore, not entirely unexpected, though the apparent degree of proliferative activity was, nevertheless, much greater than would have been expected from the apparently quiescent appearance of the villous trophoblast on light microscopic examination. This may, however, be a reflection of the fact that PCNA staining tends to overestimate the degree of proliferative activity in a tissue due to retention of staining in post-mitotic cells. ${ }^{30}{ }^{31}$

In partial hydatidiform moles the percentage of villous cytotrophoblastic cells staining positively for PCNA was, on average, lower than that in placentas from hydropic abortions. This indicates that undue trophoblastic proliferation-hyperplasia-is not a feature of partial hydatidiform moles and indeed any critical review of the histology of partial moles would confirm that this is so in most, though admittedly not all, partial moles. Most partial moles show, in fact, very little trophoblastic proliferation and in most the degree of such proliferation is lower than in normal first trimester placentas. It is the pattern, rather than the degree of trophoblastic proliferation, which is abnormal in partial moles, the villous trophoblast showing focal, multifocal, or circumferential proliferation rather than the polar or lateral proliferation seen in the normal placenta.

It could be argued, when considering these results, that fetal death occurs earlier in pregnancy in hydropic abortions than in partial hydatidiform moles and that therefore these two groups are not strictly comparable. This may be true but further supports our view that trophoblastic proliferation is not a feature of partial moles. If fetal death had occurred at a later stage of gestation in a non-molar abortion, the proliferative activity in the trophoblast in the abortion material would probably have been higher and would further exceed that seen in partial moles. It could further be argued that sampling error may have led to the missing of foci of trophoblastic hyperplasia in the partial hydatidiform moles. There is no reason to believe, however, that the sampling error in placental tissue from partial moles was any greater than in that from surgically terminated pregnancies or from hydropic abortions. Furthermore, if trophoblastic hyperplasia was so focal in partial moles that its presence could be missed as a result of sampling error in all the cases examined it could hardly be argued that hyperplasia of the trophoblast is a defining feature of a mole. Therefore, neither of these arguments detract from the finding that the degree of trophoblastic proliferation in partial hydatidiform moles is less than is that in both normal first trimester placentas and in placental tissue from hydropic abortions.

Staining of villous cytotrophoblastic cells for PCNA indicates clearly that trophoblastic hyperplasia is not, despite statements to the contrary, a feature of partial hydatidiform moles. Thus any attempt to distinguish between placentas from hydropic abortions and partial moles which is based on the supposed differences in trophoblastic proliferative activity between these two conditions will, as in this study, be doomed to failure.

1 Javey H, Borazjani G, Behmard S, Langley FA. Discrepancies in the histological diagnosis of hydatidiform mole. Br $\mathcal{F}$ Obstet Gynaecol 1979;86:480-3.

2 Messerli ML, Parmley T, Woodruff JD, Lilienfeld AM, Bevilacqua L, Rosenheim NB. Inter- and intra-pathologist variability in the diagnosis of gestational trophoblastic gist variability in the diagnosis of gestational

3 Szulman AE, Surti U. The syndromes of hydatidiform mole. II. Morphologic evolution of the complete and partial II. Morphologic evolution of the complete
mole. Am 7 Obstet Gynaecol 1978;132:20-7.

4 Elston CW. The pathology of trophoblastic disease: current status. Clinics Obstet Gynaecol 1984;11:135-52.

5 Szulman AE. Trophoblastic disease: complete and partial hydatidiform moles. In: Perrin EVDK, ed. Pathology of the placenta. New York: Churchill Livingstone, 1984 183-97. 
6 Elston CW. Gestational trophoblastic disease. In: Fox H, ed. Haines and Taylor: obstetrical and gynaecological pathology. Edinburgh: Churchill Livingstone, 1987:1045-78.

7 Szulman AE. The biology of trophoblastic disease: complete and partial hydatidiform moles. In: Beard RW, Sharp F, eds. Early pregnancy loss: mechanisms and treatment. London: Springer-Verlag, 1988:309-18.

8 Elston $\mathrm{CW}$. Trophoblastic disease: a review' with emphasis on recent advances and problems in differential diagnosis. In: Damjanov I, Cohen AH, Mills SE, Young RH, eds. Progress in reproductive and urinary tract pathology, Vol 1 . Progress in reproductive and urinary tract

9 Mazur MT, Kurman RJ. Gestational trophoblastic disease. In: Sternberg SS, Mills SE, eds. Surgical pathology of the female reproductive system and peritoneum. New York: Raven Press, 1991:1-16.

10 Kurman RJ. Pathology of trophoblast. In: Kraus FT, Damjanov I, Kaufman N, eds. Pathology of reproductive failure. Baltimore: Williams \& Wilkins, 1991:195-227.

11 Paradinas FJ. Pathology and classification of trophoblastic tumours. In: Coppleson M, ed. Gynaecologic oncology. 2nd ed. Edinburgh: Churchill Livingstone, 1992:1013-26.

12 Matthews MB, Berstein RM, Franza BR Jr, Garrels JI. Identity of the proliferating cell nuclear antigen and cyclin. Nature 1984;303:374-6.

13 Celis JE, Celis A. Cell cycle dependent variations in the distribution of the proliferating cell nuclear antigen in cultured cells: subdivision of $S$ phase. Proc Natl Acad Sci USA 1985;82:3262-6.

14 Bravo R, Frank R, Blundell PA, MacDonald-Bravo $\mathrm{H}$. Cyclin/PCNA is the auxiliary protein of DNA delta. Nature 1987:326:515-7.

15 Tan CK, Sullivan K, Li XY, Tan EM, Downey KM, So AG. Autoantibody to the proliferating cell nuclear antigen neutralises the activity of the auxiliary protein for polymerase delta. Nucleic Acids Res 1987:15:9299-308.

16 Waseem NH, Lane DP. Monoclonal antibody analysis of the proliferating cell nuclear antigen (PCNA): structural conservation and the detection of a nucleolar form. $7 \mathrm{Cell}$ Sci 1990;96:121-9.

17 Hall PA, Levison DA, Woods AL, et al. Proliferating cell nuclear antigen (PCNA) immunolocalisation in paraffin sections: an index of cell proliferation with evidence of sections: an index of cell proliferation with evidence of deregulated expressi

18 Zuber M, Tan EM, Ryoji M. Involvement of proliferating cell nuclear antigen (cyclin) in DNA replication in living cells. Mol Cell Biol 1989;9:57-66.
19 Garcia RL, Coltrera MD, Gown AM. Analysis of proliferative grade using anti-PCNA-cyclin monoclonal antibodies in fixed, embedded tissues: comparison with flow cytometric analysis. Am f Pathol 1989;134:733-9.

20 Hall PA, Levison DA. Assessment of cellular proliferation in histological material: $\mathcal{f}$ Clin Pathol 1990;43:184-92.

21 Hall PA, Woods PA. Immunohistochemical markers of cell proliferation: achievements, problems and prospects. Cell Tissue Kinet 1990;23:531-49.

22 Woods AL, Hall PA, Shepherd NA, et al. The assessment of proliferating cell nuclear antigen (PCNA) immunostaining in primary gastrointestinal lymphomas and its relaing in primary gastrointestinal lymphomas and its relationship to histological grade, $\mathrm{S}+\mathrm{G} 2+\mathrm{M}$ phase fraction
(flow cytometric analysis) and prognosis. Histopathology (flow cytometric

23 Brown RA, Beck JS. Statistics on microcomputers. A nonalgebraic guide to their appropriate use in biomedical research and medical practice. 3 Analysis of variance and distribution-free methods. I Clin Pathol 1988;41: 1256-62.

24 Fox H. Pathology of the placenta. Clinics Obstet Gynaecol 1986;13:501-19.

25 Geier G, Schuhmann R, Kraus H. Regionale unterschiedliche Zellproliferation innerhalb der Plazentome reifer menschlichen Plazenten: autoradiographische Untersuchungen. Arch Gynakol 1975;218:31-7.

26 Sands J, Dobbing J. Continuing growth and development of the third trimester human placenta. Placenta 1985;6: $13-22$.

27 Iversen OE, Farsund T. Flow cytometry in the assessment of human placental growth. Acta Obstet Gynaecol Scandinahuman placental growt

28 Boyd PA. Quantitative studies of the normal human placenta from 10 weeks of gestation to term. Early Hum Develop 1984;9:297-307.

29 Fox H. The placenta. In: Kovacs K, Asa SL, eds. Functional endocrine pathology. Oxford: Blackwell Scientific Publications, 1991:670-82.

30 van Dierendonck JH, Wijsman JH, Keijser R, van der Velde CJ, Cornelisse CJ. Cell-cycle-related patterns of antiproliferating cell nuclear antigen monoclonal antibodies: comparison with BrdUrd labelling and $\mathrm{Ki}-67$. Am 7 Pathol 1991;138:1165-72.

31 Scott RJ, Hall PA, Haldane JS, et al. A comparison of immunohistochemical markers of cell proliferation with experimentally determined growth fraction. I Pathol 1991;165:173-8. 